Research Article

\title{
A Study to assess the Internet Gaming Disorder (IGD) among Adolescent Students of Kashmir
}

\author{
Massrat Majeed', Mohammad Ayoub Dar', Perkash Kour $^{3}$, Nazira Shaban ${ }^{4}$ \\ ${ }^{1,4} \mathrm{MSc}$ Nursing Scholar, ${ }^{2,3}$ Assistant Professor, MMINSR, SKIMS, Srinagar, Jammu and Kashmir, India. \\ DOI: https://doi.org/10.24321/2348.2133.202008
}

I $\quad \begin{array}{llll}\mathbf{N} & \mathbf{F} & \mathbf{O}\end{array}$

Corresponding Author:

Massrat Majeed, MMINSR, SKIMS, Srinagar, Jammu and Kashmir, India.

E-mail Id:

massaratmajeed@gmail.com

Orcid Id:

https://orcid.org/0000-0001-7233-0605

How to cite this article:

Majeed M, Dar MA, Kour P, Shaban N. A Study to assess the Internet Gaming Disorder (IGD) among Adolescent Students of Kashmir. Ind J Holist Nurs 2020; 11(4): 26-31.

Date of Submission: 2020-12-09

Date of Acceptance: 2020-12-27

\section{$\begin{array}{llllllll}\mathbf{A} & \mathbf{B} & \mathbf{S} & \mathbf{T} & \mathbf{R} & \mathbf{A} & \mathbf{C} & \mathbf{T}\end{array}$}

Background: Gaming is a legitimate leisure activity worldwide; however, there are emerging concerns that vast numbers of gamers are becoming addicted. In 2013, the American Psychiatric Association (APA) classifies Internet Gaming Disorder (IGD) as a condition warranting more clinical research ahead of formalising it as a mental disorder. Proposed as a behavioural addiction, Internet Gaming Disorder (IGD) shares many similarities in both physical and psychological manifestations with substance use disorder, including cerebral changes on functional magnetic resonance imaging. Among the gaming population, adolescents demonstrate far more addictive internet gaming use in terms of screen hours, craving, and negative impacts on health, which have, in isolated incidents, also caused death.

Worldwide addiction to gamers among adolescents is becoming a serious concern. This study was conducted to assess the occurrence of IGD among adolescent students in a selected Higher secondary school of Kashmir.

Methodology: Quantitative methodology with a cross-sectional research design study was conducted among adolescent students of a selected higher secondary school. 220 students were included in the study by non-probability convenience sampling technique. English version of IGD-20 test was used to assess the problem. Statistical analysis used descriptive statistics that were represented with frequencies and percentages. $\mathrm{P}<0.05$ was considered as statistically significant.

Results and Conclusion: An overall occurrence of IGD was $15.7 \%$ among adolescent students and it was higher among male students than female students, which was found statistically significant with a $p$ value of $<0.049$.

Keywords: Internet Gaming Disorder, IGD, Gaming Disorder, Occurrence, Adolescent Students

\section{Introduction}

Internet Gaming Disorder (IGD) comprises a behavioural pattern encompassing persistent and recurrent engagement with both online and offline games, leading to significant impairment or distress over a twelve months period. ${ }^{1}$

With the popularity of high-tech devices (computer, tablet,

Indian Journal of Holistic Nursing (ISSN: 2348-2133)

Copyright (c) 2020: Author(s). Published by Advanced Research Publications 
and smartphone), and internet use in recent years, playing online or offline games has become a popular activity, especially among young people. People usually play games for entertainment, excitement, challenge seeking, emotional coping, and for escaping from reality to virtuality to full fill their unsatisfied needs or motivations. ${ }^{2}$

Although some studies have demonstrated some beneficial effects of playing games on physical and psychological health, ${ }^{3,4}$ most of the research on internet gaming has focused on the negative effects on gamers. It has been suggested that excessive gaming behaviour is associated with reduced sleep time, limited leisure activity, insomnia, ${ }^{5}$ attention problems, poor academic performance, ${ }^{6}$ anxiety, depressive symptoms, deterioration of interpersonal relationships and youth violence or crimes. ${ }^{2}$

The most active adopters of internet and modern technologies have been adolescents and young adults, reflecting the fact they have grown up in an environment with a well-developed internet. According to World Health Organization (WHO), out of 7.2 billion people worldwide, over 3 billion are younger than 25 years, making up $42 \%$ of the world's population. Around 1.2 billion of these young people are adolescents aged between 10 and 19 years. ${ }^{7}$ India has the largest adolescent population in the world, 253 million, and every 5th person is between 10 to 19 years of age. ${ }^{8}$

Rohillia (2018) conducted an investigation to study the prevalence of gaming addiction among adolescent students of Chandigarh, India and found that among males $62.35 \%$ were normal gamers and $37.64 \%$ were problem gamers whereas $89.32 \%$ of the females were normal gamers and $10.68 \%$ were problem gamers. ${ }^{9}$

Despite the rising game related figures in India, there is a paucity of knowledge regarding the prevalence of IGD in India. Cases of IGD in India are being surfaced only through suicidal, homicidal cases or severe psychosocial impairments, and the same is true for our region. Successful prevention depends on the knowledge of the cause and the identification of risk factors and risk groups. Based on the studies and articles reviewed, it is evident that internet gaming disorder is taking the form of an emerging disorder among adolescents. DSM-5 and ICD-11 also agree on the need for research in the said area. Apart from that, the researcher's own observations, watching young adults busy and occupied with their smartphones, playing games and wasting their career building days, motivated the researcher to take up the current study to assess the extent to which pathological gamers exist in our region as no such study has been conducted till now.

\section{Material and Method}

Ethical clearance was obtained from the Institutional Ethics
Committee prior to the start of the study. Permission was taken from the school authorities after explaining the importance of the study. Data were collected after obtaining consent from study participants.

This study was carried on a sample of 220 adolescent students studying in the selected higher secondary school of Sopore, Baramulla, Kashmir. The sample was selected through a non-probability convenience sampling technique. The inclusion criteria were as follows:

- Adolescent students who were studying in classes 9th, 10th, 11th, and 12th,

- Adolescent students who were available at the time of the study,

- Adolescent students who willingly participated in the study

The exclusion criteria were as follows:

- Adolescent students who were not available during data collection,

- Adolescent students who were not willing to participate

Duration of Study: Four weeks

The data collection was made through online administration of data collection tool, which consists of the following three parts:

Part A: This Included the items related to demographic variables: gender, education of father, education of mother, occupation of father, occupation of mother, type of family, residence, and socioeconomic status of family.

Part B: This Included two items, one for screening gamers among adolescent students and the second item was related to the time spent by the gamer class of adolescent students in playing games per week.

Part C: This was filled only by the gamer class of adolescent students. It included a standardised 20-item IGD-20 test scale for assessing the occurrence of IGD. The scale consisted of 20 items represented by 6 factors (salience, mood modification, tolerance, withdrawal, conflict, relapse) of Internet gaming disorder which were to be scored on fivepoint scale, viz. 1-strongly disagree, 2-disagree, 3-uncertain, 4-agree, 5-strongly agree. The total score ranged from 20 to 100 . The gamers were classified into 5 classes as per the total score obtained, the first and second classes represented casual gamers and regular gamers respectively, who scored below the mean average of IGD-20 test scale. These two classes being were distinguished on the basis of time spent by the gamers in playing games per week. The third and fourth class represented low risk engaged gamers, and high risk engaged gamers respectively, scoring above the mean average score in IGD-20 test. The high risk engaged gamers scored much higher on conflict and relapse factors, while the low risk engaged gamers scored higher 
in salience, mood modification, tolerance, and withdrawal factors. The fifth class represented the disordered gamers that scored above cut-off (71).

Data analysis was done by SPSS software v.16.0. Descriptive statistics were represented with frequencies and percentages. $\mathrm{P}<0.05$ was considered as statistically significant.

\section{Result}

The findings of the study are discussed as follows.

Table I.Socio-demographic Profile of the Study Group

\begin{tabular}{|c|c|c|c|}
\hline \multicolumn{2}{|c|}{$\begin{array}{c}\text { Socio-demographic Profile } \\
\text { of the Study Group }\end{array}$} & \multirow{2}{*}{\begin{tabular}{|c|}
$\begin{array}{c}\text { Frequency } \\
\text { (f) }\end{array}$ \\
121
\end{tabular}} & \multirow{2}{*}{\begin{tabular}{|c|} 
Percentage \\
56
\end{tabular}} \\
\hline Gender & Male & & \\
\hline Gender & Female & 99 & 44 \\
\hline \multirow{5}{*}{$\begin{array}{l}\text { Education } \\
\text { of father }\end{array}$} & Illiterate & 7 & 3 \\
\hline & Middle pass & 25 & 12 \\
\hline & $\begin{array}{l}\text { Higher } \\
\text { secondary }\end{array}$ & 43 & 19 \\
\hline & Graduation & 77 & 35 \\
\hline & $\begin{array}{l}\text { Post- } \\
\text { graduation }\end{array}$ & 68 & 31 \\
\hline \multirow{5}{*}{$\begin{array}{l}\text { Education } \\
\text { of mother }\end{array}$} & Illiterate & 20 & 9 \\
\hline & Middle pass & 37 & 17 \\
\hline & $\begin{array}{l}\text { Higher } \\
\text { secondary }\end{array}$ & 81 & 36 \\
\hline & Graduation & 54 & 25 \\
\hline & $\begin{array}{l}\text { Post- } \\
\text { graduation }\end{array}$ & 28 & 13 \\
\hline \multirow{3}{*}{$\begin{array}{l}\text { Occupation } \\
\text { of father }\end{array}$} & $\begin{array}{c}\text { Govt. } \\
\text { Employee }\end{array}$ & 166 & 76 \\
\hline & Self-employed & 54 & 24 \\
\hline & Unemployed & 0 & 0 \\
\hline \multirow{2}{*}{$\begin{array}{l}\text { Occupation } \\
\text { of mother }\end{array}$} & Employed & 81 & 37 \\
\hline & Unemployed & 139 & 63 \\
\hline \multirow{2}{*}{$\begin{array}{l}\text { Type of } \\
\text { family }\end{array}$} & Joint & 62 & 28 \\
\hline & Nuclear & 158 & 72 \\
\hline \multirow{2}{*}{ Residence } & Town & 99 & 45 \\
\hline & Village & 121 & 55 \\
\hline \multirow{5}{*}{$\begin{array}{l}\text { Socio- } \\
\text { economic } \\
\text { status of } \\
\text { family }\end{array}$} & Upper class & 116 & 53 \\
\hline & $\begin{array}{l}\text { Upper middle } \\
\text { class }\end{array}$ & 46 & 21 \\
\hline & Middle class & 31 & 14 \\
\hline & $\begin{array}{l}\text { Lower middle } \\
\text { class }\end{array}$ & 17 & 7 \\
\hline & Lower class & 10 & 5 \\
\hline
\end{tabular}

Table 1 reveals that 121 (56\%) students were male and 99 (44\%) were female. The education status of fathers of $35 \%$ of the students was graduation, that of $31 \%$ was postgraduation, $19 \%$ was higher secondary, $12 \%$ was middle pass, and $3 \%$ was illiterate. The education status of mothers of $36 \%$ of the students was up to higher secondary, $25 \%$ was graduation, $17 \%$ was middle pass, $13 \%$ was post-graduation, and $9 \%$ was illiterate. The occupation of father of $76 \%$ of the students was Govt. employee and $24 \%$ were selfemployed, and the mothers of $63 \%$ of the students were unemployed while that of $37 \%$ were employed. $72 \%$ of the students were living in nuclear families and $28 \%$ were living in joint families. $55 \%$ of the students belonged to villages while $45 \%$ were from towns. Majority of the students (53\%) belonged to upper class families, followed by upper middle class families (21\%), $14 \%$ were from middle class families, $7 \%$ were from lower middle class families, and $5 \%$ belonged to lower class families.

Table 2.Distribution of Adolescent Students as per their Gaming Behaviour

\begin{tabular}{|c|c|c|}
\hline Gaming Behaviour & Frequency (f) & Percentage \\
\hline Gamers & 216 & 98 \\
\hline Non-gamers & 04 & 2 \\
\hline Total & 220 & 100 \\
\hline
\end{tabular}

Table 2, shows that $98 \%$ of the students were gamers i.e., they had played video games in the last 12 months, and $2 \%$ are were non-gamers i.e., they had not played any kind of video game in the last 12 months.

\section{Table 3.Distribution of Gamer Class of Adolescent Students as per the Time Spent in Playing Games per Week}

\begin{tabular}{|c|c|c|}
\hline $\begin{array}{c}\text { Hours of Game Play/ } \\
\text { Week }\end{array}$ & $\begin{array}{c}\text { Frequency } \\
\text { (f) }\end{array}$ & Percentage \\
\hline Less than 7 hours & 116 & 54 \\
\hline 7 to 20 hours & 74 & 34 \\
\hline 20 to 40 hours & 20 & 9 \\
\hline $\begin{array}{c}\text { More than } 40 \\
\text { hours }\end{array}$ & 6 & 3 \\
\hline Total & 216 & 100 \\
\hline
\end{tabular}

Table 3, shows that $54 \%$ of the students played games for less than 7 hours/ week, 34\% played games for about 7 to 20 hours/ week, $9 \%$ played for 20 to 40 hours/ week, and $3 \%$ played games for more than 40 hours per week.

Table 4 , shows that $36.1 \%$ of the gamers were casual gamers, $16.7 \%$ were regular gamers, $8.3 \%$ were low-risk gamers, $23.1 \%$ were high-risk gamers, and $15.7 \%$ were disordered gamers. 
Table 4.Frequency and Percentage Distribution of Gamer Class of Adolescent Students as per IGD 20 Test Score

\begin{tabular}{|c|c|c|}
\hline Gamer Classes & Frequency (f) & Percentage \\
\hline Casual gamers & 78 & 36.1 \\
\hline Regular gamers & 36 & 16.7 \\
\hline $\begin{array}{c}\text { Low-risk engaged } \\
\text { gamers }\end{array}$ & 18 & 8.3 \\
\hline $\begin{array}{c}\text { High-risk engaged } \\
\text { gamers }\end{array}$ & 50 & 23.1 \\
\hline Disordered gamers & 34 & 15.7 \\
\hline Total & 216 & 100 \\
\hline
\end{tabular}

Table 5 , shows that the mean \pm SD was $39.73 \pm 8.55$ for casual gamers, $43.11 \pm 8.23$ for regular gamers, $60.50 \pm$ 4.51 for low-risk engaged gamers, $62.46 \pm 4.98$ for high-risk engaged gamers, and $78.59 \pm 5.30$ for disordered gamers.

It was found that out of 216 students playing games, 34 were meeting the criteria of internet gaming disorder, and among them, 21 were males and 13 were females.
Table 5.Descriptive Statistical Table showing Mean and SD of IGD-20 Test Score among Gamer Classes

\begin{tabular}{|c|c|c|}
\hline Gamer Class & Mean \pm SD & f \\
\hline Casual gamers & $39.73 \pm 8.55$ & 78 \\
\hline Regular gamers & $43.11 \pm 8.23$ & 36 \\
\hline Low-risk engaged gamers & $60.50 \pm 4.51$ & 18 \\
\hline High-risk engaged gamers & $62.46 \pm 4.98$ & 50 \\
\hline Disordered gamers & $78.59 \pm 5.30$ & 34 \\
\hline Total & & 216 \\
\hline
\end{tabular}

The data presented in Table 6 indicates that there was a statistically significant association between Internet gaming disorder (IGD) and the demographic variable, of gender ( $p=0.049)$, whereas no significant association was found between internet gaming disorder and other demographic variables like education of father $(p=0.544)$, education of mother $(p=0.295)$, occupation of father $(p=0.983)$, occupation of mother ( $p=0.863)$, type of family $(p=0.475)$, residence $(p=0.937)$, and socioeconomic status of family ( $p=0.761)$.

Table 6.Association of Internet Gaming Disorder (IGD) with Selected Demographic Variables

\begin{tabular}{|c|c|c|c|c|c|c|}
\hline \multicolumn{2}{|c|}{ Disordered Gamers } & \multirow{2}{*}{ Mean } & \multirow{2}{*}{ SD } & \multirow{2}{*}{$\mathbf{N}$} & \multirow{2}{*}{$P$ value } & \multirow{2}{*}{ Result } \\
\hline Variables & Options & & & & & \\
\hline \multirow{2}{*}{ Gender } & Male & 77.19 & 4.00 & 21 & \multirow{2}{*}{0.049} & \multirow{2}{*}{ Significant } \\
\hline & Female & 80.85 & 6.47 & 13 & & \\
\hline \multirow{5}{*}{$\begin{array}{l}\text { Education of } \\
\text { father }\end{array}$} & Illiterate & 79.00 & 1.83 & 4 & \multirow{5}{*}{0.544} & \multirow{5}{*}{$\begin{array}{c}\text { Not } \\
\text { Significant }\end{array}$} \\
\hline & Middle Pass & 76.00 & 5.29 & 3 & & \\
\hline & Higher Secondary & 80.33 & 6.43 & 3 & & \\
\hline & Graduate & 79.75 & 6.06 & 16 & & \\
\hline & Post Graduate & 76.38 & 4.44 & 8 & & \\
\hline \multirow{5}{*}{$\begin{array}{c}\text { Education of } \\
\text { mother }\end{array}$} & Illiterate & 79.67 & 6.41 & 6 & \multirow{5}{*}{0.295} & \multirow{5}{*}{$\begin{array}{c}\text { Not } \\
\text { Significant }\end{array}$} \\
\hline & Middle Pass & 75.40 & 3.71 & 5 & & \\
\hline & Higher Secondary & 81.50 & 4.44 & 8 & & \\
\hline & Graduate & 77.91 & 5.17 & 11 & & \\
\hline & Post Graduate & 77.00 & 6.38 & 4 & & \\
\hline \multirow{3}{*}{$\begin{array}{l}\text { Occupation of } \\
\text { father }\end{array}$} & Govt. Employed & 78.60 & 5.51 & 25 & \multirow{3}{*}{0.983} & \multirow{3}{*}{$\begin{array}{c}\text { Not } \\
\text { Significant }\end{array}$} \\
\hline & Self-employed & 78.56 & 5.00 & 9 & & \\
\hline & Unemployed & & & & & \\
\hline \multirow{2}{*}{$\begin{array}{c}\text { Occupation of } \\
\text { mother }\end{array}$} & Employed & 78.38 & 5.69 & 13 & \multirow{2}{*}{0.863} & \multirow{2}{*}{$\begin{array}{c}\text { Not } \\
\text { Significant }\end{array}$} \\
\hline & Unemployed & 78.71 & 5.19 & 21 & & \\
\hline \multirow{2}{*}{ Type of family } & Joint Family & 79.33 & 6.01 & 15 & \multirow{2}{*}{0.475} & \multirow{2}{*}{$\begin{array}{c}\text { Not } \\
\text { Significant }\end{array}$} \\
\hline & Nuclear Family & 78.00 & 4.76 & 19 & & \\
\hline \multirow{2}{*}{ Residence } & Town & 78.50 & 5.71 & 14 & \multirow{2}{*}{0.937} & \multirow{2}{*}{$\begin{array}{c}\text { Not } \\
\text { Significant }\end{array}$} \\
\hline & Village & 78.65 & 5.15 & 2 & & \\
\hline
\end{tabular}




\begin{tabular}{|c|c|c|c|c|c|c|}
\hline \multirow{5}{*}{$\begin{array}{l}\text { Socio economic } \\
\text { status of family }\end{array}$} & Upper class & 79.00 & 5.62 & 14 & \multirow{5}{*}{0.761} & \multirow{5}{*}{$\begin{array}{c}\text { Not } \\
\text { Significant }\end{array}$} \\
\hline & Upper middle class & 77.00 & 6.55 & 8 & & \\
\hline & Middle class & 78.50 & 4.32 & 6 & & \\
\hline & Lower middle class & 77.00 & 4.24 & 2 & & \\
\hline & Lower class & 81.25 & 4.11 & 4 & & \\
\hline
\end{tabular}

\section{Discussion}

\section{Occurrence of Internet Gaming Disorder}

The study found that overall 12 month occurrence estimate of Internet Gaming Disorder (IGD) was $15.7 \%$ among adolescents.

Similar results were published by Lopez, Honrubia, Griffiths (14.6\%).10 In contrast to this, lower prevalence rates (3.50\%) were reported by Undavalli, Rani, Kumar (3.50\%). ${ }^{11}$

The adolescents of our Union Territory are drawn towards mobile phones and computers because of the less availability of recreational sources available to them. Apart from that, frequent shutdowns and harsh winters confine people to their homes where they do not find any recreational source apart from computers and mobile phones. The high occurrence of IGD in the present study might be attributed to that.

\section{Gender}

The occurrence of IGD was high among male students as out of the total adolescent students meeting the criteria of Internet Gaming Disorder (IGD) and categorised as disordered gamer class, $62 \%$ were male and only $38 \%$ were females. This was found to be statistically significant with a $p$ value of $<0.049$.

Majority of the studies reported similar findings of high rates among males like Muller KW, Janikan $\mathrm{M}$, Dreier $\mathrm{M}$ (3.1\%),12 and Undavalli, Rani, Kumar (8.8\%). ${ }^{11}$

From the studies, it is evident that gender acts as an important non-modifiable risk factor for IGD. Males tend to play more games than females as video games are marketed more towards boys than females and there are not many games that attract females. Male students have easy and early accessibility to gaming gadgets like mobile phones and computers as compared to female students.

\section{Parent's Education}

Higher education among parents was observed as a factor among adolescents with IGD, as out of 34 students who presented with IGD, the fathers of $47.05 \%$ of the students were graduate, $23.5 \%$ were post-graduate, $8.82 \%$ were educated up to higher secondary, $8.82 \%$ were middle pass, and $11.76 \%$ were illiterate. With regard to mother's education, maximum (32.3\%) were graduate, $11.76 \%$ were post-graduate, $23.52 \%$ were educated up- to higher secondary, $14.70 \%$ were middle pass, and $17.64 \%$ were illiterate. The result was not statistically significant with a $p$ value $<0.544$ for the education of fathers and $p$ value $<$ 0.295 for the education of mothers.

The chances of using modern technology and gadgets increase with increased literacy level at home. So, this might be the reason for this finding.

\section{Parent's Occupation}

Among 34 students who presented with IGD, fathers of $73.5 \%$ of the students were govt. employees, and $26.5 \%$ were self-employed. Spending quality time with children, and supervising their activities is difficult for a working parent. This was found statistically insignificant with $p$ value $<0.983$ for occupation of father and $p$ value $<0.863$ for occupation of mother. Contrary to this, majority of the students i.e., $62.0 \%$ with IGD had unemployed mothers and only $38 \%$ of students had mothers who were employed.

\section{Type of Family}

In the present study, majority of students with IGD i.e., $55.88 \%$ hailed from nuclear families and $44.11 \%$ belonged to joint families. The results were found statistically insignificant with $p$ value $<0.475$.

Lack of interaction among family members of nuclear families, lack of supervision, and easy access to gadgets may be the reason.

\section{Residence}

Majority of participants with IGD were from villages (58.82\%) and the rest $(42.18 \%)$ were from towns. The result was not statistically significant with $p$ value $<0.937$.

The availability of outdoor recreational activities may be more in towns as compared to villages. Hence the young adults of villages tend to stay at home and are drawn towards multi-media.

\section{Socio-economic Status}

In the present study, it was found that the majority of students i.e., $41.17 \%$ with IGD belonged to upper class families, $23.5 \%$ belonged to upper middle class families, $17.64 \%$ belonged to middle class families, $5.88 \%$ belonged to upper lower families, and $11.76 \%$ belonged to lower class families, which was not found to be statistically significant with $p$ value $<0.761$. 
Availability of smartphones and computers in upper class families from a very young age may be a factor responsible for IGD.

\section{Conclusion}

The study found that the overall occurrence of Internet Gaming Disorder (IGD) was $15.7 \%$ among adolescent students. The occurrence of Internet Gaming Disorder (IGD) was significantly associated with Gender gender $(p<0.05)$. whereas no significant association was found with other demographic variables like education of father, education of mother, occupation of father, occupation of mother, type of family, residence, and socioeconomic status of family.

\section{Source of Funding}

The author received no financial support for the research, authorship, and/ or publication of this article.

\section{Conflict of Interest: None}

\section{References}

1. Pontes HM, Macur M, Griffiths MD. Internet Gaming Disorder among Slovenian primary schoolchildren: Findings from a nationally representative sample of adolescents. Behav Addict 2016; 5(2): 304-10.

2. Wan CS, Chiou WB. Why are adolescents addicted to online gaming? An interview study in Taiwan. Cyber Psychol Behav 2006; 9(6): 762-6.

3. Cole H, Griffiths MD. Social interactions in massively multiplayer online role-playing gamers. Cyber Psychol Behav 2007; 10(4): 575-583.

4. Blumberg FC, Altschuler EA, Almonte DE et al. The impact of recreational video game play on children's and adolescents' cognition. New Directions for Child and Adolescent Development 2013; 2013(139): 41-50.

5. Rehbein F, Kleimann M, Mossle T. Prevalence and risk factors of video game dependency in adolescence: results of a German nationwide survey. Cyber Psychol Behav Soc Netw 2010; 13(3): 269-277.

6. Gentile D. Pathological video-game use among youth ages 8 to 18: A national study. Psychol Sci 2009; 20(5): 594-602.

7. World Health Organization [Internet]. Adolescent health. Geneva (Switzerland): WHO: 2020 [cited 2020 Sep 23]. Available from: https://www.who.int/healthtopics/adolescent-health

8. UNICEF [Internet]. Adolescent development and participation. New York (USA): UNICEF [cited 2019 Dec 19]. Available from: https://www.unicef.org/india/ what-we-do/adolescent-development-participation

9. Rohillia S. Prevalence of gaming addiction among adolescents. Int J App/ Sci Engi Tech 2018; 6(1): 518524.

10. Lopez-Fernandez O, Honrubia-Serrano L, Baguley T et al. Pathological video game playing in Spanish and
British adolescents: Towards the exploration of internet gaming disorder symptomatology. Comp Hu Behav 2014; 41: 304-312.

11. Undavalli VK, Rani GS, Kumar JR. Prevalence of internet gaming disorder in India: a technological hazard among adolescents. Int J Comm Med Publ Health 2020; 7(2): 688-693.

12. Muller KW, Janikan M, Dreier $M$ et al. Regular gaming behaviour and internet gaming disorder in European adolescents: Results from a cross-sectional representative survey of prevalence, predictors and psychological correlates. Eur Child Adolesc Psychiatry 2015; 24(5): 565-74. 